EVALUATING ENTREPRENEURSHIP TRAINING PROGRAM FOR KEAKSARAAN FUNGSIONAL PROGRAM AT KECAMATAN GUNUNGHALU

\author{
Nurlaeni \\ SMK Putra Gunung Halu \\ nurlaeni1708@gmail.com
}

\begin{abstract}
Keaksaraan Fungional (KF) program faces challenges for its participants still face issues post-program, specifically economic welfare related issues. Various programs have been organised to supplement KF. Among them, is entrepreneurship training and life skills training. This research attempts to evaluate such program held at Desa Pandansari, Kecamatan Gununghalu, specifically at the community of Karya Lestari Community Learning Center (CLC) using the responsive evaluation model. Generally, the program showed positive results and have been successful in engaging its participants to be more responsive when facing economic challenges in daily life.
\end{abstract}

Keywords: Keaksaraan Fungsional, Entrepeneurship, Bakery, Sewing, Training

\title{
INTRODUCTION
}

Keaksaraan Fungsional (further referred to as $\mathbf{K F}$ ) is a program for remedying reading incapability organised by a Community Learning Centre (CLC/PKBM) and ran by Family Welfare Program Team (PKK Team) and Community Education (CE/PLS/PM) (Irmawati, 2015). The program runs for six months, two classes in a week. The duration of a class adapts with learners' condition, considering the majority of them working as farmers.

In Kecamatan Gununghalu, there are six learning groups, each consisting of an average of 10 people varying by age. Among them are a majority of productive age learners, ranging from 30 years old to 45 years old. The program's history records graduating many learners. The problem is that they remain unemployed, unskilful, and powerless in facing present age economic challenges. Their knowledge remains limited to the capability of reading letters, rendering them impossible to establish new job opportunities. For those who are farmers, they can still do daily work at the field. However, their sales remain low due to low selling power from the farmers' side.

Such condition urges for a third party who facilitates necessary knowledge and skills to empower them. They need a program that may encourage them to bolster their entrepreneurship motivation and spirit, making full use of all resources at their disposal for their own welfare. For that purpose, KF incorporates the bolstering of entrepreneurship motivation and spirit in its program.

This research aims to evaluate the newly reinforced KF program. Whether the program succeeds in achieving its intended goal or not might have an impact on the future of the 
program, as well as the community itself. By pointing out the strengths and weaknesses of the program, the organiser may conduct necessary actions to improve the program, thus indirectly affecting their community of learners as well.

\section{Similar Papers}

Several researchers have conducted similar researches regarding entreprenurship program. In addition, some of them have even conducted similar trainings themselves to various communities throughout the country.

Juwono, Kurniawan and Supriyana (2017) organised their own training for a community at Desa Klampok, Kecamatan Purworejo Klampok, Kabupaten Banjarnegara. The training enables the community to create herbal medicines and package them into sachettes. They concluded their discussion about the tranining in three statements. First, boiled herb prescriptions for cronic diseases and herbal ointments are new for their target community. They are used to creating boiled herb prescriptions for stamina enhancement. They need further guidance to further their products into the commercial market. Second, they will use e-commerce websites to promote their products, making use of the popular online shopping app Tokopedia to facilitate transactions. Third, and last, business management trainings, marketing strategy trainings, and capital access knowledges opens new opportunities and knowledge for the community, motivates them to develop their business, and enables access to business capitals.

Hapsari, et al. (2017) organised an entreprenrurship training targeted at women in PKK Bibis Luhur RW 22. They concluded, in the discussion, that their program works as intended. Their participants can understand the importance of having their own business to improve their economic welfare. As an addition, they now have enough skill acquisition to bake their own cakes, enabling an opportunity to create small-scale bake stores in their own community.

Considering the above findings, we may conclude that various entrepreneurship trainings benefit the target community. It enables them access to various businessrelated knowledges, such as business management, market strategy, and business capital access. In addition, it appears as a trend that a training of skills usually follows entrepreneurship trainings. Our first finding incorporates e-commerce and herbal medicine creation skills, while our second finding incorporates small-scale business and bakery skills.

\section{METHOD}

This section consists of two subsections. The first subsection will discuss the method implemented in the training, while the second subsection will discuss the method implemented in evaluating the training.

\section{Training Method}

There are three phases of the training program. 


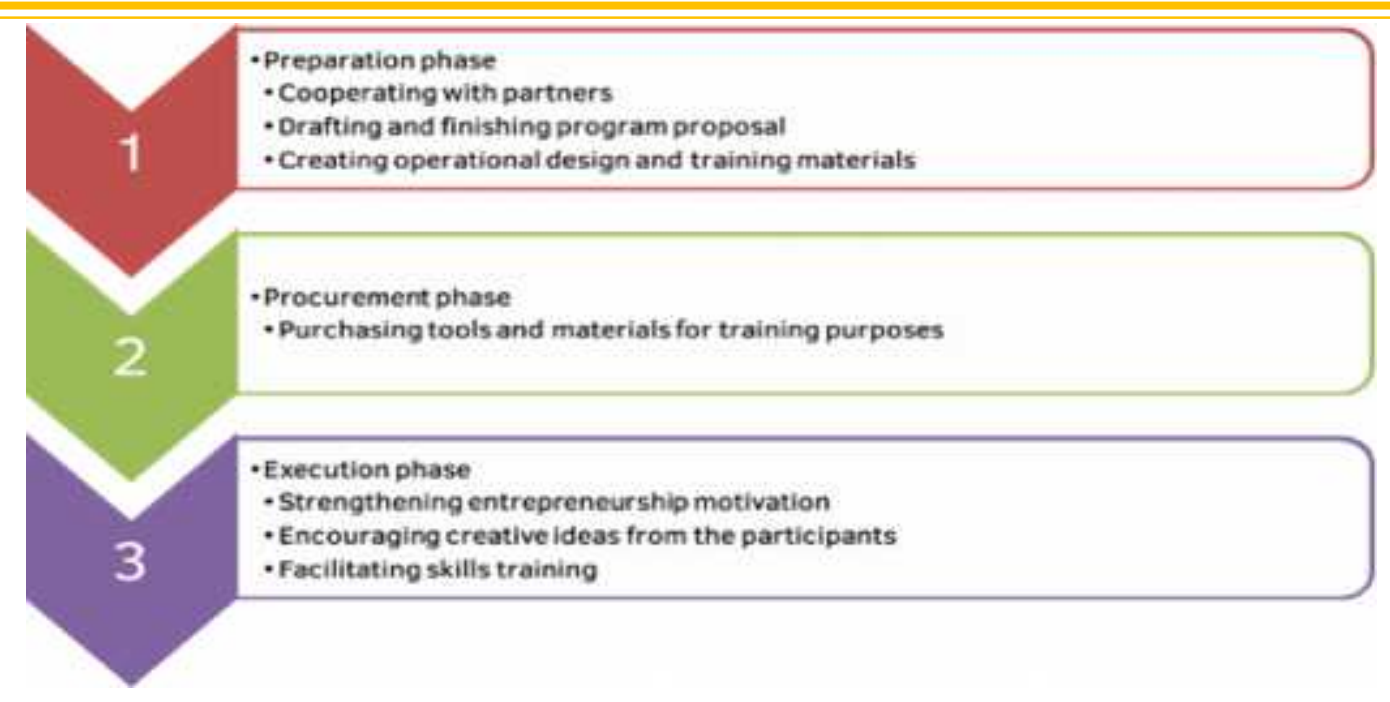

Figure 1. Three Phases of the Program

The first phase is the preparation phase. Organisers establish cooperation with partners, draft and finish program proposal, and create operational design and training materials. The second phase is the procurement phase. Organisers purchase necessary tools and materials for training purposes. The final phase is the execution phase. Before facilitating skills training, organisers attempt to strengthen participants' entrepreneurship motivation and encourage them for creative ideas.

There are twenty participants of this program; all of them are from Ciimbang CLC. There are two separate skills trained in the program: bakery (10 participants) and sewing (10 participants). Despite the small number, the organisers expect the participants to spread their knowledge to people they know after the training.

The program uses interactive-applicative method, involving the participants in various training activities. It uses theoretical test and practice tests to assess and evaluate training performance. Evaluated aspects include preparation, process (workflow and systematics), result, attitude and spent time. Theoretical tests are tests with answer keys as a comparer. To identify the program's effects on their knowledge of entrepreneurships, the organisers use one group pretest-posttest method.

\section{Research/Evaluation Method}

This research is a program evaluation research; drawing from an educational program, the research attempts to evaluate the program's performance using a specified model. In this case, we use Robert Stake's Responsive Evaluation model. This model is appropriate because it evaluates an educational program by comparing the program activity, the program uniqueness, and the social diversity of its participants.

For the reason specified above, this research uses qualitative approach and descriptive method. We use both primary and secondary data. We gather primary data from observation results, while the secondary data is from the program's performance data that includes participants' data, program description, supporting infrastructures, program curriculum, and participants' evaluation data. 
Robert Stake's Responsive Evaluation Model (Stake, 2003)

This approach enables evaluation of a specific education program by comparing the program activity, the program uniqueness, and the social diversity of its people. The most important feature of this model is the participants' responsiveness to main issues and problems (Stake, 2014). In our case, we attempt to see how responsive the participants are to the economic issues they face in daily life settings.

This model emphasises (Sanders \& Miller, 2010):

1. Educational problem over objectives or hypotheses

2. Program participation, direct or indirect (in this case, direct program participantion)

3. Continuous attention to information needs of the participants and media for reporting

To further fit the model with our context, we modified the model design, being as follows (Stake, 2003). First, we identify the scope of our training program (Cameron, 2014; Judith, 2015; Ngwiri, 2016). From it we draw an overview of the activities the program will do (Kurniawati \& Zulfiati, 2018). We will then discover the purpose of the program and its concerns toward the well-being of its participants. Next, we attempt to describe ('conceptualise') issues and problems the participants face, being specific toward economic issues and problems. We identify what form of data we will need to enable program evaluation. If we deem plausible, we handpick observers, judges, and instruments to use in evaluating the program. In addition, we place the researcher as the observer, judge, and instrument of evaluation. The observer observes experiences, transactions and outcomes the program produces. Finally, we thematise and prepare descriptions about the program and its performance, drawing from the data we obtain through observation and necessary secondary data.

\section{RESULTS AND DISCUSSION}

\section{Results}

In this section, we will present descriptions regarding all forms of findings throughout the program. We will present both primary and secondary data in a contextual format.

\section{Program Overview}

The training program enables participants to bolster their entrepreneurship motivation and spirit through trainings in various fields. In addition to entrepreneurship-related skills, the program also involves training its participants in bakery skills and sewing skills. This program is a supplementary addition to the traditional Keaksaraan Fungsional (KF) program, enabling its participants to further their skills and expertise. This is in to prevent them from being unemployed and struggling against daily economic issues through skills and self-reliance, making use of all sorts of resources available to the participant.

\section{Supporting Infrastructures}

Before the program started, the organiser paid a visit to the chief of Desa Pandansari and the head of Karya Lestari CLC, both situated in Kecamatan Gununghalu. In the visit, the organisers introduce themselves and presents the program to the villagers. Both the village and the CLC agree to support this program by providing them with participants. 
In addition, in the program, specifically in both the bakery training skill and the sewing training skill, there are several tools needed for it to succeed. The organiser purchased bakery-related tools and sewing-related tools before the program begins.

\section{Participants Profile}

There are twenty participants of the program. Ten of them specialises themselves in bakery, while ten others focuses on sewing skills. The following table presents the composition of participants grouped by their age groups.

Table 1. Program participants grouped by age

No. Age Group Bakery Sewing

\begin{tabular}{|cccc|}
\hline $\mathbf{1}$ & $20-30$ & 1 & 3 \\
\hline $\mathbf{2}$ & $31-40$ & 4 & 6 \\
\hline $\mathbf{3}$ & $41-50$ & 4 & 1 \\
\hline $\mathbf{4}$ & $>50$ & 1 & - \\
\hline & Total & 10 & 10 \\
\hline
\end{tabular}

A majority of participants in both skill groups come from the second age group, $31-40$ years old, being 10 participants in total. Following this is the $41-50$ years old age group, being five participants in total. The 20 - 30 years old age group has four participants, one in the bakery skill group while the rest is in the sewing skill group. Finally, there is one bakery skill participant aged older than 50 years old. Interestingly enough, there are no participants aged younger than 20 years old.

\section{Program Goals}

The ultimate goal of the program is to bolster the participants' motivation and spirit in entrepreneurship. Specifically, there are eight expected behaviours for the participants to show after the program:

a. Confidence

The participants are to show behaviours that indicate their assurance and optimism to start something new.

b. Basic Business Knowledge

In order to support the participants in their entrepreneurship experience, they are to show their knowing in basic business.

c. Risk-taking

A common perception among the participants is that they are afraid to take risks. This training attempts to remove such perception and encourage them to take risks and love facing and overcoming challenges.

d. Leadership

The participants are to show qualities of a leader. Specifically, they are to behave like a leader expected by the community they live in. Among all the qualities, the most important ones, according to the organiser, is that they are able to socialise with their surroundings and accept criticisms from others.

e. Innovation and Creativity

Participants are to show creativity and the power of innovation, creating something new by fully making use of all available resources for their own benefit. This further enables them to open job opportunities for others. 
f. Future-oriented

The organisers expect participants to think and consider their future when making decisions especially those related to the business they will hold.

g. Honesty

The values of telling something as is, or the value of being truthful, is among the expected values the participants must show after the program.

h. Thorough planning

The participants are to show their qualities in making and deciding plans. This involves creating detailed plans before deciding any action, especially those regarding the business they will own.

\section{Bakery and Sewing Curriculum}

It is worth mentioning that the two programs above are, if not the only, main supporting skills trained in the program. As such, it is important to describe their curriculum.

The bakery skill training attempts to enrich participants' knowledge and improve their skills in baking various cakes using available farm resources. By mastering bakery skills trained in the program, the participants are to use it in opening their own small-scale bakery business. The materials are theory and practice sessions, $10 \%$ and $90 \%$ of them respectively. The theory sessions implements classical lectures, while the practice sessions enables participants to try the skills themselves with in-between questions. In addition, the produced cakes are apple pies, basil sticks, banana crackers and cassava crackers.

The sewing skill attempts to further participants' knowledge and bolster their skills in sewing various products, including (but not limited to) fashion, bed linen, mukena (Muslim women prayer dresses), and accessories. By mastering the skill, they are to use it in opening their own small-scale clothing and/or accessory store. The materials' composition are similar to that of the bakery skill; the difference is that this is $30 \%$ and $70 \%$ instead of $10 \%$ and $90 \%$. The methods used in each session is the same: lectures for theory sessions and live practice with in-between questions for practice sessions. The theory sessions cover knowledge related to introduction to sewing tools, operating sewing tools, knowledge of textile materials, making patterns, sewing by patterns and embedded entrepreneur skills. The practice sessions cover the following aspects:

1. Body measurement practice

To obtain best sewing results, they need fine sewing patterns. To achieve such level of fineness, the participants must measure the target body thoroughly.

2. Basic pattern creation

Sewing patterns are fabric or paper cuts used as an example to sew clothings. The cuts follow clothing design size, body shape and specified models. In sewing, patterns are especially important. Whether the fashion product fits or not ultimately depends on the rightness of the pattern. Without patterns, they can create clothing products but with undesirable results. In training sessions, participants learn to create basic sewing patterns for shirts and trousers they wear themselves.

3. Cutting materials

Cutting sewing materials aims to separate fabric parts based on created pattern. A good cut is a clean one, where the edges separates from one another and it fits with the previously created pattern (Ernawati, 2008, in Sunyoto \& Sutjahjanti, 2015). 
Failure in cutting may result in material and time losses, and there are no undoings in cutting failures.

4. Sewing materials

Participants sew materials by joining fabric cuts based on specified pattern. The technique used in sewing must abide by the fabric material used. Inappropriate technique may result in unrepairable loss and less-quality sewings, at its least.

\section{Program Achievements}

The organizer has conducted necessary phases to evaluate the program results. There are two kinds of evaluation done by the organiser: theory and practice. Theory evaluation involves a set of paper questions that participants must answer. The organisers compare the participants' anwers to a predefined answer key and grade them accordingly. Practice evaluation involves participants working on a project, assessing their preparation, process (work systematics and work steps), result, attitude, and time spent on the project. The organiser scores each aspect according to a predefined set of criterions printed and available in a scoring sheet.

There is a formula used by the organisers to grade the performance of each participant. The organiser use the same formula in both sewing and bakery. The formula considers both practice and theory, weighing them $60 \%$ and $40 \%$ each, and is as follows.

$$
\text { Final }=\frac{60 \% P S+40 \% T S}{100}
$$

where

Final is the final score of a participant

PS is the score of a participant's practice performance

TS is the score of a participant's performance in the theory evaluation

According to the above formula, the scale of the final score is from zero to 100 . A participant passes the training if they achieve score higher than 50 . The following table lists each participant and their performance scores. 
Table 2. Participants Performance, Graded

\begin{tabular}{|c|c|c|c|c|}
\hline \multirow{2}{*}{ Name } & \multirow{2}{*}{ Skill Group } & \multicolumn{2}{|c|}{ Score } & \multirow{2}{*}{ Final } \\
\hline & & TS & PS & \\
\hline Laila & Bakery & 70 & 74 & 72,40 \\
\hline Yayuk & Bakery & 75 & 70 & 72,00 \\
\hline Anik & Bakery & 74 & 76 & 75,20 \\
\hline Luluk & Bakery & 78 & 79 & 78,60 \\
\hline Sayidah & Bakery & 78 & 79 & 78,60 \\
\hline Masruhah & Bakery & 75 & 77 & 76,20 \\
\hline Kholifah & Bakery & 70 & 78 & 74,00 \\
\hline Niamah & Bakery & 75 & 76 & 76,00 \\
\hline Tatik & Bakery & 75 & 78 & 76,80 \\
\hline Sri & Bakery & 79 & 79 & 79,00 \\
\hline Zunik & Sewing & 70 & 74 & 72,40 \\
\hline Utaruila & Sewing & 75 & 70 & 72,00 \\
\hline Eni & Sewing & 74 & 76 & 75,20 \\
\hline Suyatmi & Sewing & 78 & 79 & 78,60 \\
\hline Kurnia & Sewing & 78 & 79 & 78,60 \\
\hline Murjiati & Sewing & 75 & 77 & 76,20 \\
\hline Lutfiana & Sewing & 77 & 80 & 78,50 \\
\hline Ima & Sewing & 75 & 80 & 77,50 \\
\hline Tita & Sewing & 75 & 80 & 77,50 \\
\hline Nafi'ah & Sewing & 79 & 79 & 79,00 \\
\hline & & & rerage & 72,59 \\
\hline
\end{tabular}

From the above table, we can conclude that all of the participants pass the training above the predefined passing score criteria. In addition, according to the organisers' statement and their internal evaluation results, they have reached the following conclusions.

Before the training program, there were only $5 \%$ of the participants showing exceptionally high level of confidence. The remaining $45 \%$ of them showed high level of confidence, while $50 \%$ of them showed an average level. After the program, there are $15 \%$ of the participants showing exceptionally high level of confidence, $75 \%$ showing high level, and the remaining $10 \%$ of them showed average level. We may conclude that the program has been generally successful in improving the participants' self-esteem level. 
Before the training program, there were only $25 \%$ of the participants showing high level of basic business knowledge understanding, 60\% showing average level and 15\% showing relatively low level. After the program, there are $15 \%$ of the participants showing exceptionally high level of basic business knowledge understandimg, 60\% showing high level, and 25\% showing average level. We may conclude that the program has generally been successful in enriching the participants' understanding of basic business knowledge.

Prior to the program, there were only $5 \%$ of the participants showing very high level of risk-taking behaviour (willing to take risks). Forty percent of them showed high level and $55 \%$ of them in average level. After the program, there are $25 \%$ of the participants showing very high level of risk-taking behaviour and $75 \%$ of them showing high level. We may conclude, from the provided numbers, that the program has generally been successful in empowering its participants to be more willing to take risks.

Prior to the program, there were only $20 \%$ of the participants showing high level of leadership behaviour. Seventy percent of them showed average level and $10 \%$ of them in relatively low level. After the program, there are $15 \%$ of the participants showing very high level of leadership behaviour and $85 \%$ of them showing high level. We may conclude, from the provided numbers, that the program has generally been successful in strengthening its participants' qualities in leadership.

Before the training program, there were only $20 \%$ of the participants showing high level of creativity and innovation. The remaining $60 \%$ of them showed average level, while $20 \%$ of them showed relatively low level. After the program, there are $5 \%$ of the participants showing exceptionally high level of creativity and innovation, 70\% showing high level, and the remaining $25 \%$ of them showed average level. We may conclude that the program has been generally successful in enriching participants' creativity and innovation power.

Before the training program, there were only $15 \%$ of the participants showing very high level of future-oriented behaviour, 35\% showing high level and 50\% showing average level. After the program, there are $20 \%$ of the participants showing exceptionally high level of future-oriented behaviour, 70\% showing high level, and $10 \%$ showing average level. We may conclude that the program has generally been successful in engaging the participants to consider their future in decision-making considerations.

Prior to the program, there were $90 \%$ of the participants showing very high level of honesty. The remaining $10 \%$ of them showed average level. After the program, there are $30 \%$ of the participants showing very high level of honesty, $65 \%$ of them showing high level and $5 \%$ of them showing average. We may conclude, from the provided numbers, that there is a decline in the honesty behaviour level shown by the participants after participating the program.

Before the training program, there were only $20 \%$ of the participants showing high level of planning. The remaining $65 \%$ of them showed average level, while $15 \%$ of them showed relatively low level. After the program, there are $15 \%$ of the participants showing exceptionally high level of planning, 75\% showing high level, and the remaining $10 \%$ of them showed average level. We may conclude that the program has 
been generally successful in engaging its participants in planning before taking any action.

\section{Discussion}

In this section, we will analyse our findings and relate them with the responsive evaluation model design.

The responsive evaluation model emphasises educational problem over objectives or hypotheses. From the above data, we may see that the program did not emphasise educational problem. Instead, it focuses on how participants show expected behaviours after participating in the program. There are no stages of improvement in the training process that tries to solve participants' problems while performing various activities. By analysing it with Robert Stake's Responsive Evaluation Model, we can define the scope of the training program. The program limits itself to economic issues the participants face.

Participants participate the program directly, adding a point to program participation aspect of the emphasised points. The organiser engage them in various activities, ranging from classical theory lectures to live demonstrations of taught skills. This enables the participants to involve themselves in learning, providing the much-needed field experience in skill mastery. According to Robert Stake's Responsive Evaluation Model, this program values direct participation over indirect ones.

The program provided continuous attention to information needs of the participants and media for reporting. They have been cooperative with the researcher in providing data and explanations regarding the program. In addition, participants' need of information has been extensive; they were providing them with post-program career or job opportunities, or further supported in running their own small-scale business.

Furthering our statement at the first paragraph of this section about the scope of the program, we state that the organiser has defined the scope of the program clearly. It limits the program to two specific supplementary skills-bakery and sewing-and incorporate entrepeneurship knowledge and attitude in between. According to Robert Stake's Responsive Evaluation Model, the program runs this activity overview. In addition, they have also limited the participants to twenty people. This is because overnumbered participants may hinder the organisers to run the training program effectively. In addition, they are also running the program specifically in Desa Pandansari and Karya Lestari CLC community.

We have discussed the overview of program activities in the previous section. In addition, the program's purposes and concerns have been specific-that is, to improve the economic welfare condition of its participants through entrepeneurship and lifeskill utilisation by making use of available resources fully. The program has also addressed issues and problems faced by the participant-being mostly economic welfare-related issues.

The researcher acts as the observer, judge, and research instrument. To evaluate the program, the researcher gathers both primary data by interviewing organisers and secondary data by utilising the data provided in the program's public report. 
By identifying the data we need, we discovered that we need descriptive data regarding the participants' experiences to enable evaluation of the program. We have obtained it by observing their activities and act as a research instrument to interview the participants and the organiser. The participants experience both theoretical learning and live-practice learning. The organiser have theories presented in classical lectures and grade them through classical paper-based test. In addition, to apply learned theories, they also organise live-practice sessions where participants may directly involve themselves in activities that uses their skills. They bake and create cakes or sew clothing products systematically until they made a product meaningful for themselves.

From the eight points presented in the previous section, as well as the internal scoring results, we may conlude that the participants generally experience learning benefits from the training. In general, they show changing attitudes regarding to eight aspects measured by the program. In addition, they also showed knowledge and skilfulness in either bakery or sewing, compared to prior experiences. The outcome of this program has generally been positive, since it achieves what it intends to do.

\section{CONCLUSION}

This conclusion draws from Robert Stake's Responsive Evaluation Model. The scope of this program limits its intention to addressing only economic-related issues its participants face. As such, the purpose of this program solely aims to help solve participants' economic issues and problems, at the same time improving their economic well-being. The issues and problems participants face mostly relates to economic issues: poverty and unemployment are two among the commons. The form of data we need will be a description of participants' experiences during the program, as well as additional descriptive and statistical data from the organisers. In addition to handpicked observers, judges, and evaluation instruments, we place the researcher as observers, judges, and evaluation instruments. From the generally positive remarks from the participants and organisers, we conclude that the program has been successful to achieve its intended goal.

\section{REFERENCES}

Cameron, B. (2014). Using responsive evaluation in Strategic Management. Strategic Leadership Review, 4(2), 22-27.

Hapsari, D. I., Sugiarti, S., Sugiyarmasto, S., D. N., Y. J., \& Widyastuti, E. (2017). Pelatihan Kewirausahaan "Pemberdayaan PKK Bibis Luhur RW 22 Sebagai PKK yang Siap Berbisnis." Journal of Health, 4(1), 21. https://doi.org/10.30590/vol4-no1-p21-24

Irmawati, A. (2015). PEMBELAJARAN KEAKSARAAN FUNGSIONAL PEKERJA BURUH GENDONG DI PASAR GIWANGAN YOGYAKARTA. Fakultas Ilmu Pendidikan.

Judith, K. (2015). Strategic Management Practices and Challenges at Nandi County Government. IOSR Journal of Humanities and Social Science, 2(1), 5-14.

Juwono, W. P., Kurniawan, Y. D., \& Supriyana, N. (2017). Teknologi pembuatan obat herbal dan paking sachet bagi Kelompok Dasa Wisma Pengelola Apotik Hidup di Desa Klampok, Kec. Purworejo Klampok, Kab. Banjarnegara. ITEKS, 9(2), 7-14. 
Kurniawati, \& Zulfiati. (2018). Evaluasi Program Pembelajaran Sejarah Terintegrasi dalam Mata Pelajaran IPS di SMPN 4 Kota Bekasi. Jurnal Pendidikan Sejarah, 7(1), $1-28$.

Mulyono, D. (2017). Menegaskan Karakter Pendidikan Nonformal. Empowerment, 1(1).

Ngwiri, M. W. (2016). Strategic management practices, organizational culture and organizational performance: a case study of PZ Cussons East Africa.

Sanders, J. R., \& Miller, R. (2010). The Oral History of Evaluation: The Professional Development of James R. Sanders. American Journal of Evaluation, 31(1), 118-130. https://doi.org/10.1177/1098214009346332

Stake, R. (2003). Responsive Evaluation BT - International Handbook of Educational Evaluation. In T. Kellaghan \& D. L. Stufflebeam (Ed.) (hal. 63-68). Dordrecht: Springer Netherlands. https://doi.org/10.1007/978-94-010-0309-4_5

Stake, R. (2014). Information science and responsive evaluation. E-Learning and Digital Media, 11(5), 443-450. https://doi.org/10.2304/elea.2014.11.5.443

Sunyoto, S., \& Sutjahjanti, A. (2015). EFEKTIVITAS PELATIHAN KETRAMPILAN WIRAUSAHA BAGI KELOMPOK BELAJAR KEAKSARAAN FUNGSIONAL DI DESA PANDANSARI. SISTEM Jurnal Ilmu Ilmu Teknik, 11(2), 42-53. 